\title{
The relation between dietary intakes and psychological disorders in Iranian adults: a population-based study
}

\author{
Zohreh Sadat Sangsefidi ${ }^{1,2}$, Masoud Mirzaei $^{3}$ and Mahdieh Hosseinzadeh ${ }^{1,2^{*}}$ (D)
}

\begin{abstract}
Background: Previous studies showed an association between dietary intakes and psychological disorders. This study aimed to assess the association between dietary intakes and psychiatric disorders in Iran.

Methods: In this cross sectional research, the data on 9965 adults were extracted from enrollment phase of Yazd Health Study (YaHS); a population-based cohort study on Iranian adults which was conducted during 2014 to 2016. Data on socio-demographic characteristics, tobacco use, history of chronic disease, and dietary assessment were collected using a validated researcher-made questionnaire. Moreover, anthropometric measurement was conducted. Psychological and physical activity assessments were also performed by depression, anxiety and stress scale questionnaire (DASS 21 items) and the short form of the International Physical Activity Questionnaire (IPAQ) respectively. Finally, multiple logistic regression analysis was used to evaluate relation between dietary intakes and psychological disorders.
\end{abstract}

Results: After adjusting for the confounders, egg (depression: $\mathrm{OR}=0.72,95 \% \mathrm{Cl}: 0.52-0.98$; anxiety: $\mathrm{OR}=0.72, \mathrm{Cl}$ : $0.55-0.94$ ), fruits (depression: $\mathrm{OR}=0.60,95 \% \mathrm{Cl}: 0.43-0.82$; anxiety: $\mathrm{OR}=0.70,95 \% \mathrm{Cl}: 0.53-0.91$ ), milk (depression: $\mathrm{OR}=0.72, \mathrm{Cl}: 0.58-0.89$; anxiety: $\mathrm{OR}=0.73, \mathrm{Cl}: 0.61-0.87$ ), and yogurt (depression: $\mathrm{OR}=0.67, \mathrm{Cl}: 0.47-0.97$; anxiety: $\mathrm{OR}=0.54, \mathrm{Cl}: 0.4-0.73$ ) were found to have protective effects on depression and anxiety. Higher fish consumption was associated with greater depression odds $(\mathrm{OR}=1.54, \mathrm{Cl}: 1.18-2.04)$. Vegetables' intake had an inverse relationship with anxiety $(\mathrm{OR}=0.74, \mathrm{Cl}=0.58-0.93)$ and stress $(\mathrm{OR}=0.59, \mathrm{Cl}: 0.42-0.82)$. Fruits $(\mathrm{OR}=0.6, \mathrm{Cl}: 0.43-0.85)$ and milk consumption (OR: $0.61, \mathrm{Cl}: 0.47-0.77$ ) were found to have protective effects on stress.

Conclusions: Egg, fruits, milk, yogurt, and vegetables' consumption had an inverse relationship with psychiatric disorders; whereas, higher fish intake was associated with higher depression chance. Further prospective studies are needed to confirm these findings.

Keywords: Psychological disorders, Dietary intakes, Diet

\footnotetext{
* Correspondence: hoseinzade.mahdie@gmail.com

'Department of Nutrition, School of Public Health, Shahid Sadoughi

University of Medical Sciences, Yazd, Iran

${ }^{2}$ Nutrition and Food Security Research Center, Shahid Sadoughi University of Medical Sciences, Yazd, Iran

Full list of author information is available at the end of the article
}

(c) The Author(s). 2020 Open Access This article is licensed under a Creative Commons Attribution 4.0 International License, which permits use, sharing, adaptation, distribution and reproduction in any medium or format, as long as you give appropriate credit to the original author(s) and the source, provide a link to the Creative Commons licence, and indicate if changes were made. The images or other third party material in this article are included in the article's Creative Commons licence, unless indicated otherwise in a credit line to the material. If material is not included in the article's Creative Commons licence and your intended use is not permitted by statutory regulation or exceeds the permitted use, you will need to obtain permission directly from the copyright holder. To view a copy of this licence, visit http://creativecommons.org/licenses/by/4.0/ The Creative Commons Public Domain Dedication waiver (http://creativecommons.org/publicdomain/zero/1.0/) applies to the data made available in this article, unless otherwise stated in a credit line to the data. 


\section{Background}

Psychological disorders are not only among the diseases with the highest burden, but also among the most important risk factors of stroke, cardiovascular disease (CVD), and some cancers worldwide [1-5]. Depression, anxiety, and stress are among the most common psychological problems throughout the world $[6,7]$. The global prevalence of the major depressive symptoms and anxiety has been estimated as approximately 4.4 and 3.6\%, respectively [8]. However, the prevalence rates of anxiety and depression were reported as 21.0 and $20.8 \%$ among the Iranian adults, respectively [9].

Environmental factors including diet can influence on psychological health. Some studies evaluated the association between diet and psychological health. Nevertheless, their results are inconsistent [10-31]. For example, some evidences showed a protective effects of consuming fruits $[16-19,21,30]$ and vegetables $[16-19,21,30]$ on psychological disorders, whereas no significant impact was found in a cross sectional study from Columbia [32]. Legumes [16], dairy products [23-25], and eggs [27] were associated with decreased risk of depression. However, consumption of legumes and dairy products had no significant effect on depression in a prospective population-based study among Taiwanese older people [19]. Some studies reported a preventive role of fish intake against psychological disorders, such as depression $[16,20]$ and anxiety [28], while no significant relation was found in three cross-sectional data sets (The nationwide Health 2000 Survey, the Fishermen Study and the Finntwin16) [22]. Most previous studies were conducted among the western populations and limited results are available from non-western states, especially the Middle Eastern countries with different dietary intakes and prevalence of psychiatric disorders (e.g. 23.44\% in Iran [33] versus $18.5 \%$ in the United State [34]). A few largescale cross sectional studies evaluated the relationship between diet or dietary items and psychological health among the Iranian population $[12-15,35,36]$. These surveys either investigated the general role of diet, as a lifestyle factor, on one psychological disorder [14], or examined the role of dietary patterns $[12,13,15]$ and only special dietary items such as eggs [35] or grains [36] on psychological disorders. Only one large-scale cross sectional study specifically evaluated the association between dietary intakes and stress among Iranian adults that reported the protective effect of consuming fruits, vegetables, red meat, and dairy products on stress [31]. However, no population-based study has ever evaluated the relationship between dietary intakes and other psychiatric disorders, such as depression or anxiety among Iranian adults. Since findings of the observational studies on the relation between dietary intakes and risk of psychological disorders are contradictory and little information is available about this issue from the population base studies specially in Iran, this survey was carried out. The aim was to examine the association between dietary intakes and psychological disorders in a large representative sample of Iranian population.

\section{Materials and methods}

\section{Study population and data collection}

We used Yazd Health Study (YaHS) data for the present research. YaHS is a population-based cohort study which has been conducted among a large representative population of Iranian adults (20-69 years old) in Yazd Greater Area. The aim of YaHS was assessing the changing incidence of a variety of chronic disease and associated risk factors in Yazd. Briefly, the recruitment phase of YaHS was performed during September 2014 to March 2016. Adults $(n=10,000)$ from 200 clusters were randomly selected from Yazd population based on residential postal codes using cluster sampling method in 2014. The study was approved by the Ethics Committee of Shahid Sadoughi University of Medical Sciences, Yazd, Iran (Ethical approval code: IR.SSU.REC.1393.7341, Date: July 8, 2014). Furthermore, written informed consents were obtained from all participants. Data on socio-demographic characteristics, tobacco use, history of chronic disease, and dietary assessment were collected using a validated researcher-made questionnaire. In addition, physical activity and psychological health status were evaluated via the valid questionnaires. Anthropometric, measurements were also performed. Reliability and validity of the researchermade questionnaire was evaluated by consulting experts in each domain of it and a pilot research on 50 participants before performing the study. Reliability of the questionnaire was also confirmed by the Cronbach's alpha 0.89 . More details of YaHS has been recently published elsewhere [37].

\section{Dietary assessment}

Dietary intakes were evaluated using a valid questionnaire [37] by asking about consumptions of fruits and vegetables (serving of consumption per day: Nothing, 1, >1); milk and yogurt (serving of consumption per week: Nothing, $1-2,>2$ ), red meat, poultry, egg, legumes (frequency of consumption per week: Never, 1, >1) and fish (frequency of consumption: Never, $<1$ per week, $\geq 1$ per week).

\section{Anthropometric measurements}

Weight was measured using Omron BF511 portable digital scale and body analyzer (Omron Inc. Osaka, Japan) with accuracy of $0.1 \mathrm{~kg}$. Height was measured in a standing position using a tape measure on a straight wall to the nearest centimeter according to standard method. Body Mass Index (BMI) was also computed by dividing the body weight $(\mathrm{kg})$ by the square of height $(\mathrm{m})$. 


\section{Psychological health assessment}

The Iranian validated version of depression, anxiety and stress scale questionnaire (DASS 21 items) was used to screen the psychological disorders. DASS 21 is a short version of the self-report depression, anxiety and stress scale questionnaire with seven items per subscale [38]. Respondents read statements about these subscales and record their responses based on a 4-point Likert-type scale ranging from 0 (Did not apply to me at all) to 3 (Applied to me very much or most of the time). For each scale, the scores are summed for identified items. Since the DASS 21 is a short form version of DASS (the Long Form has 42 items), the final score of each scale needs to be multiplied by two ( 2). Finally, depression, anxiety and stress were defined as having the score of $\geq 10$, score of $\geq 8$ and score of $\geq 15$ respectively.

\section{Physical activity assessment}

Assessment of physical activity among participants was conducted using the short form of the International Physical Activity Questionnaire (IPAQ) [39]. The validity of Persian translation of this questionnaire has previously been confirmed by Moghaddam et al. [40]. Finally physical activity levels of subjects were categorized as low, medium and high according to guideline of IPAQ short form [39].

\section{Statistical analysis}

Statistical Package for Social Science (SPSS Inc., Chicago IL. Version 16.0) was applied for analysis. Frequency and percentage were used for description of qualitative variables. Logistic regression analysis was also applied to assess the relation between dietary intakes and psychological disorders in different models with adjustment for various confounders including age $(20-29,30-39,40-49,50-59$, 60-69 years), education level (secondary school and lower, high school, diploma and Graduate diploma, Bachelors, Masters and $\mathrm{PhD}$ ), having physical activity (yes/no), history of chronic diseases (yes/no, including hypertension, diabetes, cardiovascular disease, cancer, depression, dyslipidemia), smoking (yes/no) and BMI. Significance level was considered as $p<0.05$. The lowest frequency or serving of dietary intakes was considered as reference in all models.

\section{Results}

\section{Participant's characteristics}

The distribution of study population according to general characteristics has been shown in Table 1. According to the results, $50.3 \%(n=4989)$ of study population were female and rest of them were men. The participants were predominantly aged 40-49 years (20.7\%), married $(85 \%)$ and secondary school educated or beyond (54.6\%). The prevalence of smoking was $10.9 \%$. Moreover, it was found that the prevalence of overweight and
Table 1 General characteristics of study population

\begin{tabular}{|c|c|}
\hline Variables & $\begin{array}{l}\text { Total }(\boldsymbol{N}=9965) \\
\text { N (\%) }\end{array}$ \\
\hline \multicolumn{2}{|l|}{ Sex } \\
\hline Male & 4921 (49.7\%) \\
\hline Female & 4989 (50.3\%) \\
\hline \multicolumn{2}{|l|}{ Age (years) } \\
\hline $20-29$ & $1963(19.8 \%)$ \\
\hline $30-39$ & $2025(20.4 \%)$ \\
\hline $40-49$ & 2049 (20.7\%) \\
\hline $50-59$ & 1969 (19.9\%) \\
\hline $60-69$ & 1907 (19.2\%) \\
\hline \multicolumn{2}{|l|}{ Education level } \\
\hline Secondary school and lower & $5389(54.6 \%)$ \\
\hline Diploma and Graduate diploma & $2932(29.7 \%)$ \\
\hline Bachelors & $1291(13.1 \%)$ \\
\hline Masters and PhD & $254(2.6 \%)$ \\
\hline \multicolumn{2}{|l|}{ Smoking } \\
\hline Yes & $1056(10.9 \%)$ \\
\hline No & 8610 (89.1\%) \\
\hline \multicolumn{2}{|l|}{ Marital status } \\
\hline Married & $8430(85 \%)$ \\
\hline Single & $1054(10.6 \%)$ \\
\hline Widowed & $380(3.8 \%)$ \\
\hline Divorced & $55(0.6 \%)$ \\
\hline \multicolumn{2}{|l|}{ BMI } \\
\hline Low weight $(<18.5)$ & $255(2.7 \%)$ \\
\hline Normal (18.5-24.9) & $2944(31.1 \%)$ \\
\hline Overweight (25-29.9) & $3551(37.5 \%)$ \\
\hline Obesity $(\geq 30)$ & $2707(28.6 \%)$ \\
\hline \multicolumn{2}{|l|}{ Psychological status } \\
\hline \multicolumn{2}{|l|}{ Depression status } \\
\hline Normal & $8836(91.4 \%)$ \\
\hline Depression & $827(8.6 \%)$ \\
\hline \multicolumn{2}{|l|}{ Anxiety status } \\
\hline Normal & 8441 (86.8\%) \\
\hline Anxiety & $1279(13.2 \%)$ \\
\hline \multicolumn{2}{|l|}{ Stress status } \\
\hline Normal & $9026(94 \%)$ \\
\hline Stress & $1279(13.2 \%)$ \\
\hline \multicolumn{2}{|l|}{ Physical activity level } \\
\hline Low & 5059 (50.8\%) \\
\hline Medium & $4165(41.8 \%)$ \\
\hline High & 741 (7.4\%) \\
\hline
\end{tabular}


obesity among participants was 37.5 and $28.6 \%$ respectively. The findings of physical activity assessment also showed that the most of subjects (92.6\%) had low $(50.8 \%)$ or medium $(41.8 \%)$ physical activity level. Meanwhile, the prevalence of depression, anxiety and stress was estimated 8.6, 13.2 and $6 \%$, respectively.

\section{Description of dietary intakes among participants}

Findings about assessing dietary intakes among all participants have been shown in Table 2. The frequency of consumption for red meat, poultry, egg and legumes among most people was more than once per week. Although, fruits intake among most of participants was more than one serving per day, only $23.7 \%$ of individuals consumed vegetables more than one serving/day. Moreover, fish consumption once or more than once per week was observed among only $28 \%$ of subjects. While, the amount of yogurt intake among most people was more than 2 glasses per week, only $25.2 \%$ of subjects drank milk more than 2 glasses.

\section{Dietary intakes and depression}

The findings of evaluating association between dietary intakes and depression have been presented in the Table 3. After adjustment for several confounders including age, education level, physical activity, chronic diseases history, smoking history and BMI, no significant association was found between consumption of red meat and depression (Once per week: OR: 0.62, CI: 0.37-1.03; More than once per week: OR: 0.74, CI: 0.46-1.19). However, after adjusting for the confounders, fish consumption once or more than once per week was significantly associated with higher depression chance than none-consumption (OR: 1.44, CI: 1.12-1.87). This finding remained unchanged after furthermore adjustment for BMI (OR: 1.54, CI: 1.18-2.04). The persons with intake of egg more than once per week had significantly lower odds of depression in compared with subjects consumed no egg (OR: 0.72, CI: 0.52-0.98). Moreover, individuals who ate fruits more than one serving per day had $37 \%$ lower depression chance in comparison to none-consumers (OR: 0.63, CI: 0.46-0.86). This protective impact did not change after more controlling for BMI (OR: 0.6, CI: 0.43-0.82). Similarly, drinking 1-2 glasses of milk per week was meaningfully related to decreased depression chance than none-consumption (OR: 0.72, CI: 0.58-0.89). This association remained unchanged after furthermore adjustment for BMI (OR: 0.72, CI: 0.58-0.89). In addition, it was observed that subjects who consumed yogurt more than 2 glasses per week had significantly lower odds of depression than none-consumers (OR: 0.68, CI: 0.47-0.97). An additional adjustment for BMI did not change this finding (OR: 0.67, CI: 0.47-0.97). However, there was no significant relation between other dietary intakes and depression.
Table 2 Distribution of study population according to dietary intakes

\begin{tabular}{|c|c|}
\hline Dietary intakes & $\begin{array}{l}\text { Total }(\boldsymbol{N}=9965) \\
\text { N (\%) }\end{array}$ \\
\hline \multicolumn{2}{|l|}{${ }^{1}$ Red meat } \\
\hline Never & $263(2.6 \%)$ \\
\hline Once/week & $1651(16.6 \%)$ \\
\hline$>1 /$ week & 8051 (80.8\%) \\
\hline \multicolumn{2}{|l|}{${ }^{1}$ Poultry } \\
\hline Never & $291(2.9 \%)$ \\
\hline Once/week & $22,923(29.3 \%)$ \\
\hline$>1 /$ week & $6751(67.7 \%)$ \\
\hline \multicolumn{2}{|l|}{${ }^{1}$ Fish } \\
\hline Never & $2051(20.6 \%)$ \\
\hline Lower than once/week & $5123(51.4 \%)$ \\
\hline$\geq 1 /$ week & $2791(28 \%)$ \\
\hline \multicolumn{2}{|l|}{${ }^{1} \mathrm{Egg}$} \\
\hline Never & $733(7.4 \%)$ \\
\hline Once/week & $2923(29.3 \%)$ \\
\hline$>1 /$ week & 6309 (63.3\%) \\
\hline \multicolumn{2}{|l|}{${ }^{1}$ Legumes } \\
\hline Never & $187(1.9 \%)$ \\
\hline Once/week & 1770 (17.8\%) \\
\hline$>1 /$ week & 8008 (80.4\%) \\
\hline \multicolumn{2}{|l|}{${ }^{2}$ Vegetables } \\
\hline Nothing & $2432(24.4 \%)$ \\
\hline One/day & 5167 (51.9\%) \\
\hline$>1 /$ day & $2366(23.7 \%)$ \\
\hline \multicolumn{2}{|l|}{${ }^{2}$ Fruits } \\
\hline Nothing & $917(9.2 \%)$ \\
\hline One/day & $4272(42.9 \%)$ \\
\hline$>1 /$ day & 4776 (47.9\%) \\
\hline \multicolumn{2}{|l|}{${ }^{2}$ Milk } \\
\hline Nothing & 3063 (30.7\%) \\
\hline 1-2 glasses/week & $4393(44.1 \%)$ \\
\hline$>2$ glasses/week & 2509 (25.2\%) \\
\hline \multicolumn{2}{|l|}{${ }^{2}$ Yogurt } \\
\hline Nothing & $520(5.2 \%)$ \\
\hline 1-2 glasses/week & $2380(23.9 \%)$ \\
\hline$>2$ glasses/week & 7065 (70.9\%) \\
\hline
\end{tabular}

1. Dietary intakes for mentioned items were presented as frequency of consumption

2. Dietary intakes for mentioned items were presented as serving of consumption

\section{Dietary intakes and anxiety}

Table 4 shows the findings about association between dietary intakes and anxiety. Those who used egg more than once per week had meaningfully lower anxiety 
Table 3 Multivariable-adjusted odds ratios (OR) (95\% Cl) for depression across different frequencies or servings for dietary intakes in study population ( $N=9965)$

\begin{tabular}{|c|c|c|}
\hline \multirow[t]{3}{*}{ Dietary intakes } & \multicolumn{2}{|l|}{${ }^{3}$ Depression } \\
\hline & ${ }^{4}$ Multivariable adjusted & ${ }^{5}$ Multivariable + BMl \\
\hline & $\mathrm{OR}$ & OR \\
\hline
\end{tabular}

${ }^{1}$ Red meat

$$
\text { Never }
$$

Once/week

$>1 /$ week

${ }^{1}$ Poultry

Never

Once/week

$>1 /$ week

${ }^{1}$ Fish

$$
\text { Never }
$$

Lower than once/week

$\geq 1$ week

${ }^{1}$ Egg

Never

Once/week

$>1 /$ week

'Legume

Never

Once/week

$>1 /$ week

${ }^{2}$ Vegetables

Nothing

One/day

$>1 /$ day

${ }^{2}$ Fruits

Nothing

One/day

$>1 /$ day

${ }^{2}$ Milk

Nothing

1-2 glasses/week

$>2$ glasses/week

${ }^{2}$ Yogurt

Nothing

1-2 glasses/week

$>2$ glasses/week

\section{Reference}

${ }^{*} 0.6$

0.69

Reference

$0.95 \quad 0.55-1.64$

0.99

$0.58-1.67$

Reference

0.89

${ }^{*} 1.44$

Reference

0.8

0.73

Reference

1.37

1.11

Reference

0.92

0.8

Reference

0.88

*0.63

Reference

*0.72

0.99

Reference

$1.00 \quad 0.69-1.44$

*0.68 *0.47-0.97
Reference

$0.62 \quad 0.37-1.03$

$0.74 \quad 0.46-1.19$

Reference

$0.93 \quad 0.54-1.61$

$0.96 \quad 0.56-1.63$

Reference

$0.93 \quad 0.73-1.19$

*1.54 * $1.18-2.01$

Reference

$0.81 \quad 0.59-1.12$

*0.72 *0.52-0.98

Reference

1.38

1.16

$0.76-2.52$

$0.64-2.09$

Reference

$0.94 \quad 0.74-1.18$

$0.83 \quad 0.62-1.11$

Reference

$0.83 \quad 0.61-1.11$

*0.6 * $0.43-0.82$

Reference

*0.72 *0.58-0.89

$1.03 \quad 0.81-1.31$

Reference

$0.96 \quad 0.66-1.4$

*0.67 *0.46-0.97

${ }^{1}$ Dietary intakes for mentioned items were presented as frequency of consumption

2 Dietary intakes for mentioned items were presented as serving of consumption

${ }^{3}$ depression was defined as having the score of $\geq 10$ from the DASS2 1 questionnaire

${ }^{4}$ Adjusted for age (20-29, 30-39, 40-49, 50-59, 60-69 years), education level

(Secondary school and lower, High school, Diploma and Graduate diploma,

Bachelors, Masters and PhD), physical activity level (low, medium, high), history of

chronic diseases (hypertension, diabetes, cardiovascular disease, cancer, depression, dyslipidemia), smoking (yes/no)

${ }^{5}$ Adjusted for age (20-29, 30-39, 40-49, 50-59, 60-69 years), education level (Secondary school and lower, High school, Diploma and Graduate diploma,

Bachelors, Masters and PhD), physical activity level (low, medium, high), history of chronic diseases (hypertension, diabetes, cardiovascular disease, cancer, depression, dyslipidemia), smoking (yes/no) and BMI. "Significance level was considered as $p<0.05$ chance than none-consumers (OR: 0.75, CI: 0.58-0.98). This relation remained unchanged after more controlling for BMI (OR: 0.72, CI: 0.55-0.94). Furthermore, the persons with consumption of vegetables more than one serving per day had $26 \%$ lower anxiety chance in compared with those consumed no vegetables (OR: 0.74, CI: 0.58-0.93). This protective effect remained after furthermore adjustment for BMI (OR: 0.74, CI: 0.58-0.93). Similarly, the chance of anxiety among individuals who used fruits more than once serving per day was significantly lower than none-consumers (OR: 0.70, CI: 0.540.90). This finding did not change after more controlling for BMI (OR: 0.70, CI: 0.53-0.91). Moreover, drinking12 glasses of milk per week was meaningfully associated with decreased odds of anxiety than none-consumption (OR: 0.71, CI: 0.6-0.85). This association remained after furthermore adjustment for BMI (OR: 0.73, CI: 0.610.87 ). Meanwhile, anxiety chance among subjects with consumption 1-2 glasses of yogurt was significantly lower than none-consumers (OR: 0.55, CI: 0.41-0.74). An additional adjustment for BMI did not change this relation (OR: 0.54, CI: 0.4-0.73). But, no significant association was observed between other dietary intakes and anxiety.

\section{Dietary intakes and stress}

The findings of assessing the relation between dietary intakes and stress had been shown in Table 5. Vegetables consumption was inversely associated with stress (OR: 0.59, CI: $0.42-0.82$ ). This protective effect remained significant after more controlling for BMI (OR: 0.59, CI: 0.42-0.82). Similarly, fruits intake was associated with lower stress chance (OR: 0.59, CI: 0.42-0.83). This association did not change after further adjustment for BMI (OR: 0.6, CI: 0.43-0.85). It was also observed that the subjects who drank 1-2 glasses of milk per week had decreased odds of stress than none-consumers (0.60: 0.470.76). An additional adjustment for BMI did not change this finding (0.61: 0.47-0.77). However, no association was found between other dietary intakes and stress.

\section{Discussion}

The present research indicated an inverse relationship between intakes of eggs, fruits, milk, and yogurt with depression and anxiety. More consumption of vegetables might be associated with decreased odds of anxiety and stress, whereas higher consumption of fish might be related to greater chance of depression. Furthermore, an inverse association was found between intakes of fruits and milk with stress.

Similar to our results, a protective effect was reported for fruits and vegetables consumption against stress among the university students in European countries [41], the United Kingdom [21], China [30], as well as 
Table 4 Multivariable-adjusted odds ratios (OR) (95\% Cl) for anxiety across different frequencies or servings for dietary intakes in study population $(N=9965)$

\begin{tabular}{|c|c|c|c|c|}
\hline \multirow[t]{3}{*}{ Dietary intakes } & \multicolumn{4}{|l|}{${ }^{3}$ Anxiety } \\
\hline & \multicolumn{2}{|c|}{${ }^{4}$ Multivariable adjusted } & \multicolumn{2}{|c|}{${ }^{5}$ Multivariable + BMI } \\
\hline & OR & $\mathrm{Cl}$ & OR & $\mathrm{Cl}$ \\
\hline \multicolumn{5}{|l|}{${ }^{1}$ Red meat } \\
\hline Never & \multicolumn{2}{|l|}{ Reference } & \multicolumn{2}{|c|}{ Reference } \\
\hline Once/week & 1.25 & $0.79-1.98$ & 1.46 & $0.9-2.39$ \\
\hline$>1 /$ week & 1.23 & $0.8-1.91$ & 1.49 & $0.93-2.39$ \\
\hline \multicolumn{5}{|l|}{${ }^{1}$ Poultry } \\
\hline Never & \multicolumn{2}{|l|}{ Reference } & \multicolumn{2}{|c|}{ Reference } \\
\hline Once/week & 1.05 & $0.66-1.66$ & 1.11 & $0.69-1.79$ \\
\hline$>1 /$ week & 1.21 & $0.77-1.89$ & 1.27 & $0.8-2.03$ \\
\hline \multicolumn{5}{|l|}{${ }^{1}$ Fish } \\
\hline Never & \multicolumn{2}{|l|}{ Reference } & \multicolumn{2}{|c|}{ Reference } \\
\hline Lower than once/week & 0.83 & $0.69-1.01$ & 0.82 & $0.67-1.00$ \\
\hline$\geq 1 /$ week & 1.12 & $0.91-1.38$ & 1.12 & $0.9-1.39$ \\
\hline \multicolumn{5}{|l|}{${ }^{1} \mathrm{Egg}$} \\
\hline Never & \multicolumn{2}{|l|}{ Reference } & \multicolumn{2}{|c|}{ Reference } \\
\hline Once/week & 0.84 & $0.64-1.1$ & 0.82 & $0.62-1.07$ \\
\hline$>1 /$ week & *0.75 & ${ }^{*} 0.58-0.97$ & *0.72 & *0.55-0.94 \\
\hline \multicolumn{5}{|l|}{ 'Legume } \\
\hline Never & \multicolumn{2}{|l|}{ Reference } & \multicolumn{2}{|c|}{ Reference } \\
\hline Once/week & 1.2 & $0.73-1.97$ & 1.16 & $0.69-1.95$ \\
\hline$>1 /$ week & 1.01 & $0.62-1.65$ & 0.98 & $0.59-1.62$ \\
\hline \multicolumn{5}{|l|}{${ }^{2}$ Vegetables } \\
\hline Nothing & \multicolumn{2}{|l|}{ Reference } & \multicolumn{2}{|c|}{ Reference } \\
\hline One/day & 0.92 & $0.77-1.1$ & 0.93 & $0.77-1.12$ \\
\hline$>1 /$ day & ${ }^{*} 0.74$ & ${ }^{*} 0.58-0.93$ & *0.77 & ${ }^{*} 0.6-0.98$ \\
\hline \multicolumn{5}{|l|}{${ }^{2}$ Fruits } \\
\hline Nothing & \multicolumn{2}{|l|}{ Reference } & \multicolumn{2}{|c|}{ Reference } \\
\hline One/day & 0.81 & $0.64-1.03$ & 0.79 & $0.61-1.01$ \\
\hline$>1 /$ day & ${ }^{*} 0.7$ & ${ }^{*} 0.54-0.9$ & ${ }^{*} 0.7$ & ${ }^{*} 0.53-0.91$ \\
\hline \multicolumn{5}{|l|}{${ }^{2}$ Milk } \\
\hline Nothing & \multicolumn{2}{|l|}{ Reference } & Refere & \\
\hline 1-2 glasses/week & ${ }^{*} 0.71$ & ${ }^{*} 0.6-0.85$ & *0.73 & ${ }^{*} 0.61-0.87$ \\
\hline$>2$ glasses/week & 0.97 & $0.79-1.18$ & 0.98 & $0.8-1.2$ \\
\hline${ }^{2}$ Yogurt & & & & \\
\hline Nothing & Reference & & Refere & \\
\hline 1-2 glasses/week & 0.75 & $0.56-1.02$ & ${ }^{*} 0.72$ & *0.52-0.98 \\
\hline$>2$ glasses/week & *0.55 & ${ }^{*} 0.41-0.74$ & *0.54 & ${ }^{*} 0.4-0.73$ \\
\hline $\begin{array}{l}1{ }^{1} \text { Dietary intakes for ment } \\
2 \text { Dietary intakes for ment } \\
{ }^{3} \text { Anxiety was defined as h } \\
{ }^{4} \text { Adjusted for age (20-29, } \\
\text { (Secondary school and lov } \\
\text { Bachelors, Masters and Ph } \\
\text { chronic diseases (hyperter } \\
\text { dyslipidemia), smoking (ye } \\
{ }^{5} \text { Adjusted for age (20-29, } \\
\text { (Secondary school and lov } \\
\text { Bachelors, Masters and Ph } \\
\text { chronic diseases (hyperter } \\
\text { dyslipidemia), smoking (ye } \\
\text { *Significance level was cor }\end{array}$ & $\begin{array}{l}\text { ed items we } \\
\text { ed items we } \\
\text { ig the score } \\
-39,40-49, \\
\text { High schoo } \\
\text { physical act } \\
\text { n, diabetes, } \\
\text { 10) } \\
-39,40-49 \text {, } \\
\text { High schoo } \\
\text { physical act } \\
\text { n, diabetes, } \\
\text { o) and BMl } \\
\text { lered as } p<\end{array}$ & $\begin{array}{l}\text { presented a } \\
\text { presented a } \\
\text { f } \geq 8 \text { from th } \\
-59,60-69 \text { y } \\
\text { Diploma ano } \\
\text { ity level (low } \\
\text { ardiovascular } \\
\text { 0-59, 60-69 } \\
\text { Diploma ano } \\
\text { ity level (low } \\
\text { ardiovascular } \\
.05\end{array}$ & $\begin{array}{l}\text { luency } \\
\text { ing of } \\
\text { S21 qu } \\
\text { educat } \\
\text { luate di } \\
\text { lium, hi } \\
\text { se, can } \\
\text { educa } \\
\text { luate di } \\
\text { lium, hi } \\
\text { se, can }\end{array}$ & $\begin{array}{l}\text { Imumption } \\
\text { nnption } \\
\text { nnaire } \\
\text { vel } \\
\text { a, } \\
\text { istory of } \\
\text { lepression, } \\
\text { evel } \\
\text { a, } \\
\text { istory of } \\
\text { lepression, }\end{array}$ \\
\hline
\end{tabular}

Iran [31]. Fruits' intake was also associated with lower depression risk in the European countries [41] and United Kingdom [21].

In contrast to our survey, one research from Columbia showed no significant association between fruits' consumption and depression among a sample of overweight and obese women [32]. The validated short form of the Center for Epidemiological Studies Depression Scale was used for psychological health assessment in the Columbian study; while we applied the Iranian validated version of DASS 21 in this research. The differences between our results and some studies can be explained by discrepancies in the population's characteristics, dietary habits, and the applied psychological health assessment tools.

The protective effects of vegetables and fruits might be attributed to nutrients, such as carbohydrates, vitamins, antioxidants, and phytochemicals [5]. The possible association of carbohydrates contained in such foods with psychological health may be due to the secretion of insulin caused by consumption of these foods, which consequently stimulated the production of neurotransmitters such as serotonin by the entry of tryptophan into the brain [42-44]. Furthermore, the nutrients in vegetables and fruits, including folate and vitamin B6 [45], antioxidants (such as vitamins C, E) [18], phytochemicals (such as polyphenols) $[18,46]$, and minerals (such as iron, calcium and magnesium) [47] could have a protective role against the psychological problems.

The findings of the present paper are in line with the surveys from Iran [31] and Japan [23] that reported a preventive effect for intake of the dairy products on stress and depression, respectively.

Contrary to our research, no relationship was observed between the dairy products consumption and stress or depression among the university students in a survey by El Ansari et al. [21]. In the mentioned study, the Cohen's Perceived Stress Scale and modified Beck Depression Inventory were applied for examining the participants' psychological health; whereas, we used the Iranian validated version of DASS 21 in our study. The various characteristics of population, dietary habits, and different tools for assessing the psychiatric disorders in the mentioned study [21] might explain the reason of this discrepancy.

The protective role of dairy products can be related to their minerals such as calcium, because calcium, as a neurotransmitter, is critical in the function of neuromuscular tissues involved in the emotional regulation and consequently prevents from the psychological disorders [48]. Dairy products might also have a protective effect due to their antiinflammatory process [23], since they contain compounds such as calcium [49], lactoferrin [50], and bioactive peptides [51]. 
Table 5 Multivariable-adjusted odds ratios (OR) (95\% Cl) for stress across different frequencies or servings for dietary intakes in study population $(N=9965)$

\begin{tabular}{|c|c|c|c|c|}
\hline \multirow[t]{3}{*}{ Dietary intakes } & \multicolumn{4}{|l|}{${ }^{3}$ Stress } \\
\hline & \multicolumn{2}{|c|}{$\overline{{ }^{4} \text { Multivariable adjusted }}$} & \multicolumn{2}{|c|}{${ }^{5}$ Multivariable + BMI } \\
\hline & OR & $\mathrm{Cl}$ & OR & $\mathrm{Cl}$ \\
\hline \multicolumn{5}{|l|}{${ }^{1}$ Red meat } \\
\hline Never & \multicolumn{2}{|l|}{ Reference } & \multicolumn{2}{|c|}{ Reference } \\
\hline Once/week & 0.87 & $0.48-1.55$ & 0.9 & $0.5-1.73$ \\
\hline$>1 /$ week & 0.96 & $0.55-1.66$ & 1.08 & $0.6-1.94$ \\
\hline \multicolumn{5}{|l|}{${ }^{1}$ Poultry } \\
\hline Never & \multicolumn{2}{|l|}{ Reference } & \multicolumn{2}{|c|}{ Reference } \\
\hline Once/week & 1.41 & $0.73-2.74$ & 1.37 & $0.7-2.68$ \\
\hline$>1 /$ week & 1.31 & $0.68-2.51$ & 1.27 & $0.66-2.44$ \\
\hline \multicolumn{5}{|l|}{${ }^{1}$ Fish } \\
\hline Never & \multicolumn{2}{|l|}{ Reference } & \multicolumn{2}{|c|}{ Reference } \\
\hline Lower than once/week & 0.79 & $0.61-1.02$ & 0.77 & $0.59-1.01$ \\
\hline$\geq 1 /$ week & 1.2 & $0.91-1.6 ?$ & 1.22 & $0.91-1.63$ \\
\hline \multicolumn{5}{|l|}{${ }^{1} \mathrm{Egg}$} \\
\hline Never & \multicolumn{2}{|l|}{ Reference } & \multicolumn{2}{|c|}{ Reference } \\
\hline Once/week & 0.75 & $0.53-1.07$ & 0.77 & $0.54-1.11$ \\
\hline$>1 /$ week & 0.75 & $0.54-1.06$ & 0.75 & $0.53-1.07$ \\
\hline \multicolumn{5}{|l|}{${ }^{1}$ Legume } \\
\hline Never & \multicolumn{2}{|l|}{ Reference } & \multicolumn{2}{|c|}{ Reference } \\
\hline Once/week & 1.38 & $0.67-2.82$ & 1.31 & $0.63-2.7$ \\
\hline$>1 /$ week & 1.24 & $0.61-2.5$ & 1.17 & $0.58-2.38$ \\
\hline \multicolumn{5}{|l|}{${ }^{2}$ Vegetables } \\
\hline Nothing & \multicolumn{2}{|l|}{ Reference } & \multicolumn{2}{|c|}{ Reference } \\
\hline One/day & ${ }^{*} 0.72$ & ${ }^{*} 0.56-0.92$ & ${ }^{*} 0.71$ & ${ }^{*} 0.55-0.91$ \\
\hline$>1 /$ day & ${ }^{*} 0.59$ & ${ }^{*} 0.42-0.82$ & ${ }^{*} 0.59$ & ${ }^{*} 0.42-0.82$ \\
\hline \multicolumn{5}{|l|}{${ }^{2}$ Fruits } \\
\hline Nothing & \multicolumn{2}{|l|}{ Reference } & \multicolumn{2}{|c|}{ Reference } \\
\hline One/day & *0.68 & *0.5-0.92 & "0.68 & *0.5-0.94 \\
\hline$>1 /$ day & *0.59 & *0.43-0.83 & ${ }^{*} 0.6$ & *0.43-0.85 \\
\hline \multicolumn{5}{|l|}{${ }^{2}$ Milk } \\
\hline Nothing & \multicolumn{2}{|l|}{ Reference } & Refere & \\
\hline 1-2 glasses/week & ${ }^{*} 0.6$ & ${ }^{*} 0.47-0.76$ & ${ }^{*} 0.61$ & ${ }^{*} 0.47-0.77$ \\
\hline$>2$ glasses/week & 0.81 & $0.62-1.06$ & 0.77 & $0.58-1.03$ \\
\hline${ }^{2}$ Yogurt & & & & \\
\hline Nothing & Reference & & Refere & \\
\hline 1-2 glasses/week & 0.94 & $0.62-1.43$ & 0.85 & $0.56-1.3$ \\
\hline$>2$ glasses/week & 0.82 & $0.54-1.22$ & 0.74 & $0.49-1.12$ \\
\hline $\begin{array}{l}{ }^{1} \text { Dietary intakes for menti } \\
{ }^{2} \text { Dietary intakes for ment } \\
{ }^{3} \text { Stress was defined as hay } \\
\text { the DASS21 questionnaire } \\
{ }^{4} \text { Adjusted for age (20-29, } \\
\text { (Secondary school and lov } \\
\text { Bachelors, Masters and Ph } \\
\text { chronic diseases (hyperter } \\
\text { dyslipidemia), smoking (y } \\
{ }^{5} \text { Adjusted for age (20-29, } \\
\text { (Secondary school and lov } \\
\text { Bachelors, Masters and Ph } \\
\text { chronic diseases (hyperter } \\
\text { dyslipidemia), smoking (ye } \\
\text { *Significance level was cor }\end{array}$ & $\begin{array}{l}\text { d items wer } \\
\text { ed items wer } \\
\text { the score o } \\
-39,40-49,5 \\
\text { High school } \\
\text { physical acti } \\
\text { n, diabetes, } \\
\text { o) } \\
-39,40-49,5 \\
\text { High school } \\
\text { physical acti } \\
\text { n, diabetes, } \\
\text { o) and BMI } \\
\text { lered as } p<\end{array}$ & $\begin{array}{l}\text { presented a } \\
\text { presented } \\
\geq 15 \text {, score o } \\
\text {-59,60-69y } \\
\text { Diploma anc } \\
\text { ity level (low } \\
\text { ardiovascula } \\
\text {-59, 60-69y } \\
\text { Diploma anc } \\
\text { ity level (low } \\
\text { ardiovascula } \\
.05\end{array}$ & $\begin{array}{l}\text { uency o } \\
\text { ing of } \\
\text { and scc } \\
\text { educat } \\
\text { luate di } \\
\text { lium, hi } \\
\text { ase, can } \\
\text { educat } \\
\text { luate di } \\
\text { lium, hi } \\
\text { se, can }\end{array}$ & $\begin{array}{l}\text { sumption } \\
\text { umption } \\
\mathrm{f} \geq 8 \text { from } \\
\text { vel } \\
\text { a, } \\
\text { istory of } \\
\text { lepression, } \\
\text { vel } \\
\text { la, } \\
\text { istory of } \\
\text { lepression, }\end{array}$ \\
\hline
\end{tabular}

In contrast to our results, a preventive role was found for fish consumption against stress and depression in the study by El Ansari et al. [21] as well as against anxiety and depression in a research by Jacka et al. [28]. The protective impact of fish intake was attributed to its omega-3 fatty acids due to having anti-inflammatory activity in the previous studies $[52,53]$. However, fish consumption was generally low among participants of our study. Fried fish was also used by most of the consumers. It was also found that fried foods' consumption [54] and diet rich in fat [55] were related to increased depression risk caused by the production of free radicals and promotion of pro-inflammatory states $[55,56]$ that follows consumption of fried fish. Furthermore, many surveys have indicated that frying fish might lead to loss of the omega three fatty acids content in fish [57-60]. Therefore, the relationship observed between higher fish consumption and higher depression chance in our study might be explained by consumption of fried fish.

A few researches [61] evaluated association between egg intake and psychological disorders. Shafiei et al. (2017) [61] found no significant relation between egg consumption and psychiatric disorders. Evidence has shown that the nutrients including tryptophan [62], B vitamins [10, 27, 45, 63], vitamin D [64], and omega-3 fatty acids [65] can have a beneficial impact on psychological health and prevents from the psychiatric disorders. Therefore, egg consumption might be associated with decreased odds of psychological problems, because egg contains the mentioned nutrients [35].

The current survey enjoys from several strengths. To the best of our knowledge, it is the first population-based study that presents the relationship between several dietary intakes and a variety of psychological disorders including depression, anxiety, and stress within a large population in a Middle Eastern country. Moreover, we controlled for an extensive range of confounding factors that might influence the individuals' psychological status. However, our study had some limitations. First, as a cross-sectional study, it may not accurately explain the causality among the study variables. Thus, a cohort and controlled dietary study is needed to establish causality. The measurement error, as an identified feature of any dietary assessment method, was another limitation of this research. We also could not control the effect of all confounders due to the unknown or unmeasured factors. Since foods are consumed together, a single food may not completely explain the etiology of chronic disease such psychological disorders. Therefore, dietary pattern approach in future population-based studies can prepare a comprehensive picture of foods and their interactions and consider the combined effects of them. 


\section{Conclusions}

The present study showed an inverse association between consuming egg, fruits, milk, and yogurt with depression and anxiety. In addition, more consumption of vegetables might be related to decreased odds of anxiety and stress. An inverse association was observed between higher intake of fruits and milk with stress, whereas higher consumption of fish might be related to higher odds of depression. Further studies, especially population-based cohort research, are suggested to provide more conclusive evidence to explain the association between dietary intakes and psychological disorders.

\section{Abbreviations}

YaHS: Yazd health study; OR: Odds ratio; Cl: Confidence interval; CVD: Cardiovascular disease; (DASS 21 items): Depression, anxiety and stress scale questionnaire; BMI: Body mass index; IPAQ: International physical activity questionnaire

\section{Acknowledgements}

The authors appreciate Shahid Sadoughi University of Medical Sciences, Yazd, Iran for supporting this research.

\section{Authors' contributions}

M. $\mathrm{H}$ and M. M designed the study. Z. S. S and M. H conducted the statistical analysis. Z. S. S wrote the draft of manuscript. M. H and M. M critically revised the manuscript and confirmed the final version of it to submit. All authors read and approved the final version of manuscript.

\section{Funding}

The authors received no funding regarding to this study.

\section{Availability of data and materials}

The datasets used and analyzed during the present study are available from the corresponding author on reasonable request.

\section{Ethics approval and consent to participate}

This research was approved by the Ethics Committee of Shahid Sadoughi University of Medical Sciences, Yazd, Iran (Ethical approval code: IR.SSU.REC.1393.7341, Date: July 8, 2014). Moreover, written informed consents were obtained from all participants.

\section{Consent for publication}

Not applicable.

\section{Competing interests}

The authors declare no conflict of interests regarding the publication of this study.

\section{Author details}

${ }^{1}$ Department of Nutrition, School of Public Health, Shahid Sadoughi University of Medical Sciences, Yazd, Iran. ${ }^{2}$ Nutrition and Food Security Research Center, Shahid Sadoughi University of Medical Sciences, Yazd, Iran. ${ }^{3}$ Yazd Cardiovascular Research Centre, Shahid Sadoughi University of Medical Sciences, Yazd, Iran.

Received: 11 December 2019 Accepted: 18 May 2020 Published online: 24 May 2020

\section{References}

1. Murray CJ, Lopez AD. Global mortality, disability, and the contribution of risk factors: global burden of disease study. Lancet. 1997;349(9063):1436-42.

2. WHO: The World Health Report 2001: Mental health: new understanding, new hope: World Health Organization; 2001.

3. Wittchen H-U, Jacobi F, Rehm J, Gustavsson A, Svensson M, Jönsson B, Olesen J, Allgulander C, Alonso J, Faravelli C. The size and burden of mental disorders and other disorders of the brain in Europe 2010. Eur Neuropsychopharmacol. 2011;21(9):655-79.
4. Russ TC, Stamatakis E, Hamer M, Starr JM, Kivimäki M, Batty GD. Association between psychological distress and mortality: individual participant pooled analysis of 10 prospective cohort studies. BMJ. 2012;345:e4933.

5. Rooney C, McKinley MC, Woodside JV. The potential role of fruit and vegetables in aspects of psychological well-being: a review of the literature and future directions. Proc Nutr Soc. 2013;72(04):420-32.

6. Kessler RC, Chiu WT, Demler O, Walters EE. Prevalence, severity, and comorbidity of 12-month DSM-IV disorders in the National Comorbidity Survey Replication. Arch Gen Psychiatry. 2005;62(6):617-27.

7. Kessler RC, Berglund P, Demler O, Jin R, Merikangas KR, Walters EE. Lifetime prevalence and age-of-onset distributions of DSM-IV disorders in the National Comorbidity Survey Replication. Arch Gen Psychiatry. 2005;62(6): 593-602.

8. WHO: Depression and other common mental disorders: global health estimates. 2017.

9. Noorbala A, Yazdi SB, Yasamy M, Mohammad K. Mental health survey of the adult population in Iran. Br J Psychiatry. 2004;184(1):70-3.

10. Murakami K, Sasaki S. Dietary intake and depressive symptoms: a systematic review of observational studies. Mol Nutr Food Res. 2010;54(4):471-88.

11. Lai JS, Hiles S, Bisquera A, Hure AJ, McEvoy M, Attia J. A systematic review and meta-analysis of dietary patterns and depression in communitydwelling adults. Am J Clin Nutr. 2014;99(1):181-97.

12. Hosseinzadeh M, Vafa M, Esmaillzadeh A, Feizi A, Majdzadeh R, Afshar $\mathrm{H}_{\text {, }}$ Keshteli AH, Adibi P. Empirically derived dietary patterns in relation to psychological disorders. Public Health Nutr. 2016;19(02):204-17.

13. Saneei $P$, Hajishafiee $M$, Keshteli AH, Afshar $H$, Esmaillzadeh A, Adibi $P$. Adherence to alternative healthy eating index in relation to depression and anxiety in Iranian adults. Br J Nutr. 2016;116(02):335-42.

14. Saneei P, Esmaillzadeh A, Keshteli AH, Roohafza HR, Afshar H, Feizi A, Adibi $P$. Combined healthy lifestyle is inversely associated with psychological disorders among adults. PLoS One. 2016;11(1):e0146888.

15. Valipour G, Esmaillzadeh A, Azadbakht L, Afshar H, Hassanzadeh A, Adibi P. Adherence to the DASH diet in relation to psychological profile of Iranian adults. Eur J Nutr. 2017:56(1):309-20.

16. Sanhueza C, Ryan L, Foxcroft D. Diet and the risk of unipolar depression in adults: systematic review of cohort studies. J Hum Nutr Diet. 2013;26(1):5670.

17. Bishwajit G, O'Leary DP, Ghosh S, Sanni Y, Shangfeng T, Zhanchun F. Association between depression and fruit and vegetable consumption among adults in South Asia. BMC Psychiatry. 2017;17(1):15.

18. McMartin SE, Jacka FN, Colman I. The association between fruit and vegetable consumption and mental health disorders: evidence from five waves of a national survey of Canadians. Prev Med. 2013;56(3):225-30.

19. Tsai AC, Chang T-L, Chi S-H. Frequent consumption of vegetables predicts lower risk of depression in older Taiwanese-results of a prospective population-based study. Public Health Nutr. 2012;15(06):1087-92.

20. Grosso G, Micek A, Marventano S, Castellano S, Mistretta A, Pajak A, Galvano F. Dietary n-3 PUFA, fish consumption and depression: a systematic review and meta-analysis of observational studies. J Affect Disord. 2016;205:269-81.

21. El Ansari W, Adetunji H, Oskrochi R. Food and mental health: relationship between food and perceived stress and depressive symptoms among university students in the United Kingdom. Cent Eur J Public Health. 2014; 22(2):90.

22. Suominen-Taipale AL, Turunen AW, Partonen T, Kaprio J, Männistö S, Montonen J, Jula A, Tiittanen P, Verkasalo PK. Fish consumption and polyunsaturated fatty acids in relation to psychological distress. Int J Epidemiol. 2010;39(2):494-503.

23. Cui Y, Huang C, Momma H, Ren Z, Sugiyama S, Guan L, Niu K, Nagatomi R. Consumption of low-fat dairy, but not whole-fat dairy, is inversely associated with depressive symptoms in Japanese adults. Soc Psychiatry Psychiatr Epidemiol. 2017:1-7.

24. Aihara Y, Minai J, Aoyama A, Shimanouchi S. Depressive symptoms and past lifestyle among Japanese elderly people. Community Ment Health J. 2011; 47(2):186-93.

25. Miyake Y, Tanaka K, Okubo H, Sasaki S, Arakawa M. Intake of dairy products and calcium and prevalence of depressive symptoms during pregnancy in Japan: a cross-sectional study. BJOG Int J Obstet Gynaecol. 2015;122(3):33643.

26. Jacka FN, Pasco JA, Williams LJ, Mann N, Hodge A, Brazionis L, Berk M. Red meat consumption and mood and anxiety disorders. Psychother Psychosom. 2012;81(3):196-8. 
27. Ruxton C, Derbyshire E, Gibson S. The nutritional properties and health benefits of eggs. Nutr Food Sci. 2010;40(3):263-79.

28. Jacka FN, Pasco JA, Williams LJ, Meyer BJ, Digger R, Berk M. Dietary intake of fish and PUFA, and clinical depressive and anxiety disorders in women. $\mathrm{Br} J$ Nutr. 2013;109(11):2059-66.

29. Bisht AT, Kukreti VT. Food consumption pattern and lifestyle modification traits in relation to the level of stress among individuals of Uttarakhand, India. Int J Soc Sci Manage. 2016;3(4):239-45.

30. Liu C, Xie B, Chou C-P, Koprowski C, Zhou D, Palmer P, Sun P, Guo Q, Duan $\mathrm{L}$, Sun $X$. Perceived stress, depression and food consumption frequency in the college students of China seven cities. Physiol Behav. 2007;92(4):748-54.

31. Roohafza H, Sarrafzadegan N, Sadeghi M, Rafieian-Kopaei M. The association between stress levels and food consumption among Iranian population. Arch Iran Med. 2013;16(3):145.

32. Whitaker KM, Sharpe PA, Wilcox S, Hutto BE. Depressive symptoms are associated with dietary intake but not physical activity among overweight and obese women from disadvantaged neighborhoods. Nutr Res. 2014;34(4):294-301.

33. Noorbala AA, Faghihzadeh S, Kamali K, Bagheri Yazdi SA, Hajebi A, Mousavi MT, Akhondzadeh S, Faghihzadeh E, Nouri B. Mental health survey of the Iranian adult population in 2015. Arch Iran Med (AIM). 2017;20(3).

34. Bagalman E, Napili A: Prevalence of mental illness in the United States: data sources and estimates. In: Congressional Research Service; 2014.

35. Shafiei F, Keshteli AH, Pouraram H, Afshar H, Salari-Moghaddam A, Esmaillzadeh A, Adibi P. Egg consumption and prevalence of psychological disorders in adults. Eur J Nutr. 2018:1-10.

36. Sadeghi O, Hassanzadeh-Keshteli A, Afshar H, Esmaillzadeh A, Adibi P. The association of whole and refined grains consumption with psychological disorders among Iranian adults. Eur J Nutr. 2017:1-15.

37. Mirzaei M, Salehi-Abargouei A, Mirzaei M, Mohsenpour MA. Cohort profile: the Yazd health study (YaHS): a population-based study of adults aged 2070 years (study design and baseline population data). Int J Epidemiol. 2018; 47(3):697-98h

38. Sahebi A, Asghari MJ, Salari RS. Validation of depression anxiety and stress scale (DASS-21) for an Iranian population. Iran Psychol. 2005;4(1):299-313.

39. Committee IR: Guidelines for data processing and analysis of the International Physical Activity Questionnaire (IPAQ)-short and long forms. http://www ipaq ki se/scoring pdf 2005.

40. Moghaddam MB, Aghdam FB, Jafarabadi MA, Allahverdipour $\mathrm{H}$, Nikookheslat SD, Safarpour S. The Iranian version of international physical activity questionnaire (IPAQ) in Iran: content and construct validity, factor structure, internal consistency and stability. World Appl Sci J. 2012;18(8): 1073-80.

41. Mikolajczyk RT, El Ansari W, Maxwell AE. Food consumption frequency and perceived stress and depressive symptoms among students in three European countries. Nutr J. 2009;8(1):31.

42. Rao TS, Asha M, Ramesh B, Rao KJ. Understanding nutrition, depression and mental illnesses. Indian J Psychiatry. 2008:50(2):77.

43. Pasman W, Blokdijk V, Bertina F, Hopman W, Hendriks H. Effect of two breakfasts, different in carbohydrate composition, on hunger and satiety and mood in healthy men. Int J Obes. 2003;27(6):663-8.

44. Best T, Kemps E, Bryan J. Perceived changes in well-being following polysaccharide intake in middle-aged adults. Appl Res Qual Life. 2012;7(2):183-92.

45. Jacka FN, Maes $M$, Pasco JA, Williams $L$, Berk M. Nutrient intakes and the common mental disorders in women. J Affect Disord. 2012;141(1):79-85.

46. Payne ME, Steck SE, George RR, Steffens DC. Fruit, vegetable, and antioxidant intakes are lower in older adults with depression. J Acad Nutr Diet. 2012;112(12):2022-7.

47. Kaplan BJ, Crawford SG, Field CJ, Simpson JSA. Vitamins, minerals, and mood. Psychol Bull. 2007;133(5):747.

48. Bae Y-J, Kim S-K. Low dietary calcium is associated with self-rated depression in middle-aged Korean women. Nutr Res Pract. 2012;6(6):527-33.

49. Zemel MB, Sun X. Dietary calcium and dairy products modulate oxidative and inflammatory stress in mice and humans. J Nutr. 2008;138(6):1047-52.

50. Bharadwaj S, Naidu TA, Betageri GV, Prasadarao NV, Naidu AS. Inflammatory responses improve with milk ribonuclease-enriched lactoferrin supplementation in postmenopausal women. Inflamm Res. 2010;59(11):971-8.

51. FitzGerald RJ, Meisel H. Milk protein-derived peptide inhibitors of angiotensin-I-converting enzyme. Br J Nutr. 2000;84(S1):33-7.

52. Miller GE, Stetler CA, Carney RM, Freedland KE, Banks WA. Clinical depression and inflammatory risk markers for coronary heart disease. Am J Cardiol. 2002;90(12):1279-83.
53. Logan AC. Neurobehavioral aspects of omega-3 fatty acids: possible mechanisms and therapeutic value in major depression. Altern Med Rev. 2003;8(4):410-25.

54. Jacka FN, Pasco JA, Mykletun A, Williams LJ, Hodge AM, O'reilly SL, Nicholson GC, Kotowicz MA, Berk M. Association of Western and traditional diets with depression and anxiety in women. Am J Psychiatr. 2010;167(3): 305-11.

55. Pistell PJ, Morrison CD, Gupta S, Knight AG, Keller JN, Ingram DK, BruceKeller AJ. Cognitive impairment following high fat diet consumption is associated with brain inflammation. J Neuroimmunol. 2010;219(1-2):25-32.

56. Sánchez-Villegas A, Toledo E, de Irala J, Ruiz-Canela M, Pla-Vidal J, MartínezGonzález MA. Fast-food and commercial baked goods consumption and the risk of depression. Public Health Nutr. 2012;15(03):424-32.

57. Wagner K-H, Elmadfa I. Chemical and biological modulations of food due to the frying process. Int J Vitam Nutr Res. 2012;82(3):163.

58. Echarte M, Zulet MA, Astiasaran I. Oxidation process affecting fatty acids and cholesterol in fried and roasted salmon. J Agric Food Chem. 2001;49(11):5662-7.

59. Asghari L, Zeynali F, Sahari M. Effects of boiling, deep-frying, and microwave treatment on the proximate composition of rainbow trout fillets: changes in fatty acids, total protein, and minerals. J Appl Ichthyol. 2013;29(4):847-53.

60. Zhang J, Wu D, Liu D, Fang Z, Chen J, Hu Y, Ye X. Effect of cooking styles on the lipid oxidation and fatty acid composition of grass carp (Ctenopharynyodon idellus) fillet. J Food Biochem. 2013;37(2):212-9.

61. Shafiei F, Keshteli AH, Pouraram H, Afshar H, Salari-Moghaddam A, Esmaillzadeh A, Adibi P. Egg consumption and prevalence of psychological disorders in adults. Eur J Nutr. 2019;58(5):1923-32.

62. Ormstad H, Dahl J, Verkerk R, Andreassen OA, Maes M. Increased plasma levels of competing amino acids, rather than lowered plasma tryptophan levels, are associated with a non-response to treatment in major depression. Eur Neuropsychopharmacol. 2016;26(8):1286-96.

63. Murakami K, Miyake Y, Sasaki S, Tanaka K, Arakawa M. Dietary folate, riboflavin, vitamin B-6, and vitamin B-12 and depressive symptoms in early adolescence: the Ryukyus child health study. Psychosom Med. 2010;72(8): 763-8.

64. Mozaffari-Khosravi H, Nabizade L, Yassini-Ardakani SM, Hadinedoushan H, Barzegar $K$. The effect of 2 different single injections of high dose of vitamin D on improving the depression in depressed patients with vitamin $D$ deficiency: a randomized clinical trial. J Clin Psychopharmacol. 2013;33(3): 378-85.

65. Trebatická J, Dukát A, Ďuračková Z, Muchová J. Cardiovascular diseases, depression disorders and potential effects of omega-3 fatty acids. Physiol Res. 2017;(3):66.

\section{Publisher's Note}

Springer Nature remains neutral with regard to jurisdictional claims in published maps and institutional affiliations.

\section{Ready to submit your research? Choose BMC and benefit from:}

- fast, convenient online submission

- thorough peer review by experienced researchers in your field

- rapid publication on acceptance

- support for research data, including large and complex data types

- gold Open Access which fosters wider collaboration and increased citations

- maximum visibility for your research: over $100 \mathrm{M}$ website views per year

At BMC, research is always in progress.

Learn more biomedcentral.com/submissions 